\title{
EFFECTIVENESS OF VACCUM IMPREGNATION TREATMENT AND VACCUM FRYING ON STRUCTURAL, NUTRITIONAL AND SENSORY PROPERTIES OF CALCIUM FORTIFIED POTATO CHIPS
}

\author{
Pratibha Tiwari' ${ }^{1}$, Monika Thakur ${ }^{1 *}$ \\ ${ }^{1}$ Amity Institute of Food Technology, Amity University Uttar Pradesh - 201303, India \\ *mthakur1@amity.edu, monika.harsh05@gmail.com
}

https://doi.org/10.34302/crpjfst/2019.11.2.2

\begin{tabular}{ll}
\hline Article history: & ABSTRACT \\
Received: & The effectiveness of VI technology on the mineral fortification, structural \\
18 August 2018 & differences, nutritional and sensory properties of calcium fortified potato \\
Accepted: & chips was evaluated. Furthermore, vacuum frying was also performed to \\
\multicolumn{1}{c|}{ 20 May 2019 } & achieve low oil absorption for potato chips. Vacuum pressure, blanching \\
Keywords: & time, calcium concentration, were the significant variables affecting quality \\
Fortification; & attributes and mineral fortification. Targeted $25 \%$ RDI for calcium \\
Solanum tuberosum L.; & fortification could be achieved at an optimized condition of 1.33 min \\
Vaccum Impregnation; & (blanching time), $1.20 \%$ (calcium concentration), 40mm Hg (vacuum \\
SEM. & pressure), 12.01 min (restoration time). Restricted changes were recorded \\
& for hardness $(455 \mathrm{~N})$, color $(\Delta \mathrm{E}=68.54 \pm 1.93)$ and sensory score $(8.1)$ \\
& compared to the control. Structural observation reflected that although \\
& there was a deposition of calcium on the cell wall periphery, but the granule \\
appearance remained the same. Additionally, Vacuum fried calcium & fortified potato chips have shown low oil uptake percentage. Thus, VI \\
treatment and vacuum frying proved to be the most effective treatment in \\
maintaining the overall quality of potato chips.
\end{tabular}

\section{Introduction}

Potato chips account $85 \%$ of total salty snack food market consumed worldwide. Potato chips are popular for their unique characteristics such as flavor, and crispy texture. Potato based snacks have experienced an increased rate of growth over the last 20 years because snacks have become part of the main meal as well as betweenmeal nourishments. These processed foods though taste very good and are very lucrative but pose various health problems by means of - under nutrition causing nutrition deficiency and over nutrition leading to obesity, hypertension, hyperlipidemia, diabetes, cancer, and so forth. Nowadays, under nutrition especially micronutrient deficiencies are very much relevant among (Black et al., 2008) school-aged children. Worldwide, an inadequate consumption of calcium over an extended period has been found to induce calcium deficiency risk among 3.5 billion people (Kumssa et al., 2014). About calcium, per se, the recommended intake for adolescents and adults is in the range of $1000-1300 \mathrm{mg}$ per day (Food and Nutrition board, 2011). However, dietary calcium intake has been reported to be low in children (Bhatia, 2008) and adults (Harinarayan, 2007) in India. Low 
calcium intake has been reported to be associated with osteoporosis, hypertension and many more disorders (Life extension update, 2010). Most of the people fulfill their calcium demand from dairy products. However, concerns like lactose intolerance, dietary fat, cholesterol and other related allergies, among some individuals, have led to switch their preferences from dairy to nondairy products. Thus, the difference between recommended and actual calcium intake compel the manufacturers to market an increasing number and variety of calciumfortified products (Konar et al., 2015).

Food fortification, among various innovative strategies, is one of the techniques that has been harmlessly and adequately used in order to counteract micronutrient deficiencies. Among the technologies used in the development of food fortification, Vacuum Impregnation (VI) has been identified as a new processing technique based on the process of diffusion (Tiwari and Thakur, 2016). It consists of two steps, at first most air and part or all of the native solution are extracted from the porous spaces of the food (vacuum) and second replaced by an external solution when vacuum-treated samples are dipped in fortificant solution for predefined time (impregnation) (Tiwari and Thakur, 2017). It has dual advantages, firstly, it will partially dehydrate the sample and secondly, it enables to introduce controlled quantities of solute into the food particles (Torreggiani and Bertolo, 2001). Concerning VI treatment for potatoes, reports like zinc enrichment of potato tuber (Erihemu et al., 2015); ascorbic acid enrichment of whole potato tuber (Hironika et al. 2011); and calcium and zinc fortification of potato chips (Joshi et al., 2016); calcium fortification of potato chips (Tiwari et al., 2018) has been found. In light of this observation, fortification of potato chips, because of their porous matrix (1\%) and wide acceptability, with calcium will be one of the effective alternatives to overcome the problem of recommended and actual Calcium intake difference.

However, potato chips have also been reported to have an oil content ranging from 35 to $45 \mathrm{~g} / 100 \mathrm{~g}$ (wet basis) and which is a major factor affecting consumer acceptance for oil-fried products nowadays (Dueik and Bouchon, 2011). Concerning various health negative impacts, fat content of potato chips is an important parameter to be controlled during processing. Consequently, there is a demand for healthier potato-based snacks that offers the same desired organoleptic characteristics of commercially available potato chips while lowering down the fat absorption. Therefore, Vacuum frying, as an option for fried potatoes with low oil content and desired texture and flavor characteristics (Garayo and Moreira, 2002) was also taken into consideration.

Thus, in the current study, authors attempted to fortify potato chips with calcium through VI by investigating the effects of vacuum pressure, blanching time, calcium concentration, and restoration time on calcium impregnation of potato chips. Furthermore, effect of VI and Vacuum frying on quality attributes viz structure (SEM observation), color, fat content, physicochemical properties and sensory analysis, were also examined concerning desired organoleptic properties of commercially available potato chips.

\section{Materials and methods}

\subsection{Variety Selection}

Kufri chipsona-1 variety of Potatoes fresh harvest (Solanum tuberosum L.) was chosen and procured from CPRI Regional Station Modipurum, Uttar Pradesh, India.

\subsection{Fortificants and carrier}

Food grade Calcium chloride was purchased from Titen Biotech Limited, 
Delhi, India for fortification purpose. Potato chips were used as a carrier.

The standard RDI values (www.lenntech.com/recommended-dailyintake.htm 2015) of mineral were based on 2000 calorie intake (4 to 17 years of age). The research work has been planned in such a manner that the targeted level (25\% RDI for calcium) of calcium for potato chips can be achieved by consuming $30 \mathrm{~g}$ serving in accordance with Recommended Amount Customarily Consumed (RACC).

\subsection{Experimental Design}

Process optimization and product development was done using Response Surface Methodology (RSM). The combined effect of four independent variables i.e. calcium concentration, blanching time, vacuum pressure, restoration time coded as $\mathrm{X}_{1}, \mathrm{X}_{2}, \mathrm{X}_{3}, \mathrm{X}_{4}$, respectively on impregnation level of calcium in potato chips was evaluated through four-factor three level Box-Behnken design (Table 1). Optimization was done based on calcium content, hardness and overall acceptability in all experimental samples. A 27 runs (trials) were done thrice and the respective responses were observed (Table 2).

The response function was partitioned into three different components as - linear, quadratic, and interactive (Equation -1).

Where Y - response;

$\mathrm{X}_{1}, \mathrm{X}_{2}$ - input variables;

$\beta_{0}$ - intercept;

$\beta_{1}$ - linear coefficient;

$\beta_{\mathrm{ii}}$ - quadratic coefficients;

$\beta_{\mathrm{ij}-}$ interaction coefficients.

$Y=\beta_{0}+\sum_{i=1}^{k} \beta_{\mathrm{i}} \mathrm{X}_{1}+\sum_{i=1}^{k} \beta_{\mathrm{ii}} \mathrm{X}_{2} \quad+$

$\sum_{i>1}^{k} \beta_{\mathrm{ij}} \mathrm{X}_{\mathrm{i}} \mathrm{X}_{\mathrm{j}}$..................... (1)

\subsection{Vacuum Impregnation Process}

In a closed chamber, raw potato chips, after blanching at $72^{\circ} \mathrm{C}$ for predefined time, were encircled on perforated base and vacuum was created for a predefined time. When the constant level of vacuum $(15 \mathrm{~mm}$ $\mathrm{Hg}$ ) was attained for a pre-defined period, raw chips were right away dipped to impregnation/fortificant solution of particular concentrations $(1: 4(\mathrm{w} / \mathrm{v}))$ for the predetermined restoration time as per RSM design (Table 2).

\subsection{Vacuum Frying}

The experiments were performed using a vacuum fryer available at ARAS lab, Ghaziabad, U.P. The fryer consists of a heating element. Inside the vessel, there was a basket and centrifuging system (de-oiling system) with a maximum rotational speed of 750rpm (63g units). In the vessel, with a vacuum capacity of $5.37 \mathrm{kpa}$, vacuum was achieved by a dual seal vacuum pump (Model 1402 Welch Scientific Co., Skokie, IL). The frying process consists of loading 12 potato slices (about 35g) into the basked closing the lid and depressurizing the vessel. After the pressure in the vessel reached $5.37 \mathrm{kpa}$ at $120^{\circ} \mathrm{C}$ for $40 \mathrm{~min} ., 20 \mathrm{~min} / \mathrm{each}$ hours, basket was sub-merged into the oil. After 6 minutes of frying, the basket was raised, and the centrifuging system was applied for 405 at maximum speed (750rpm). Then, the vessel was pressurized, and the potato chips were allowed to cool down at ambient temperature before storing them in polyethylene bags inside of desiccators for further examination.

\subsection{Physicochemical analysis}

\subsubsection{Compositional Analysis}

The following analysis were performed in triplicate: moisture content; ash; crude protein; carbohydrate content following standard methodology by Rangana (2007) and Larmond (1977). 


\subsubsection{Mineral content estimation}

Calcium content of control, commercial, and experimental potato chips were estimated by Atomic Absorption Spectrophotometer (Shinadzu AA700) using wet ashing procedure as described by Raghuramulu et al. (2003)

\subsubsection{Oil Content}

The total lipid extraction and purification of oil content was estimated by standard methodology by Tarmizi and Niranjan (2010). This method consists of an initial extraction with a mixture of 1:2:0.8 (v/v/v) in chloroform, methanol and water. Then, this mixture was adjusted to $2: 2: 1.8(\mathrm{v} / \mathrm{v} / \mathrm{v})$ to continue further extraction. In this way, the chloroform layer contains the purified oil. The oil content was expressed as $\mathrm{kg}$ oil $/ \mathrm{kg}$ dry solid.

\subsubsection{Colorimetric measurements}

With the use of a Hunter color meter (Hunter Associates Lab Inc (Model No: LabScan XE, USA) fortified potato chips was measured for any change in color parameters (Hunter L, a, b). The color values were expressed as $\mathrm{L}$ ranged from L00 (black) to L0100 (white), $\mathrm{a}$ (greenness) to $+\mathrm{a}$ (redness), and $-\mathrm{b}$ (blueness) to $+b$ (yellowness). The instrument was calibrated before the experiments with a white ceramic plate $(\mathrm{X}=79.31, \quad \mathrm{Y}=84.11, \quad \mathrm{Z}=88.94)$. The potato chips covering the entire surface area of $1 \mathrm{~cm}$ pore, were scanned at three different locations to determine the average $\mathrm{L}^{*}, \mathrm{a}^{*}$, and $b^{*}$ values during the experiment. In addition, the total color change $(\Delta E)$ Equation (2) was also calculated from the Hunter $\mathrm{L}^{*}, \mathrm{a}^{*}, \mathrm{~b}^{*}$ scale and used to describe the total color change during fortification of potato chips.

$\Delta \mathrm{E}=\sqrt{ }(\Delta \mathrm{L} *)^{2}+(\Delta \mathrm{a} *)^{2}+(\Delta \mathrm{b} *)^{2}$. where $\Delta L *=L^{*}$ sample-

L*standard; $\Delta a *=a *$ sample-

$a^{*}$ standard; $\Delta b *=b^{*}$ sample-b*standard.

\subsection{Structural Changes through SEM}

By examining the calcium distribution in potato chips and in turn effect on granule appearances through SEM (Scanning Electron microscopy - EVO 18, Zeiss model) fortified potato chips and control samples were evaluated for their structural differences, The sample size of $1 \mathrm{x} 1 \mathrm{~cm}$ was placed on sputter coated with gold-palladium plating (of surface thickness 15 to $28 \mathrm{~nm}$ ) at 3 millibar vacuum and 15 million volt current for the time of 180 seconds. After time attainment, SEM observation were captured to evaluate the structural differences before and after fortification

\subsection{Consumer Evaluation}

The consumer sample population were selected from nearby areas of sec 125 Noida, UP, India, who were 18-55 years of age and of various socioeconomic back- grounds. Only those were selected to participate in the study, who consumed chips at least once in a month. A target of 100 participants were selected. Individual tables with written instructions and ballots were provided to consumers. Samples coded with random three-digit numbers and control potato chips were served. The consumers were asked to record the acceptability and intensity scores for overall impression, overall flavor, overall texture, overall color (9-point scale with 9 =like extremely and 1 = dislike extremely); hardness (9-point intensity scale with 9= extremely tough and $1=$ extremely soft); and crunchiness (9-point intensity scale with $9=$ extremely crunchiness and $1=$ not at all crunchy).

\subsection{Statistical analysis}

For the statistical analysis, Analysis of variance (ANOVA) and regression 
calculation using SAS (version 11) were used. All analytical measurements were taken in triplicate for each treatment. Data were analyzed using the SAS Version 5.0 software package. Means were separated using least significance difference analysis at $\mathrm{P} \leq 0.05$.

\section{Results and discussions}

Using VI technique it had been possible to raise the calcium level in potato chips from $93.3 \mathrm{mg}$ to $800 \mathrm{mg} / 100$ under the parameters of the study. The regression analysis indicated that the calcium content in potato chips was a function of vacuum pressure, restoration time, blanching time, and calcium content in impregnation solution.

\subsection{Effect of process variable on calcium impregnation}

Figure 1a (i) showed that blanching time was a quadratic function for calcium impregnation in chips i.e. with the increase in blanching time, calcium concentration in potato chips increase initially but decreased later. Maximum level of impregnation achieved at the blanching time of $1.6 \mathrm{~min}$. It was because 1.4 min was the blanching time, sufficient to enhance the desired porosity for an effective and efficient targeted impregnation level. Current findings are in line with the reports of Alzamora et al. (2005), that Blanching treatment often produces profound structural alterations (swelling of cell walls, disruption of membranes, etc.) which affects mass transport phenomena and thus resulting in the extensive uptake of solute inside the cytoplasm of parenchyma cells. However, when blanching time was increased from 1.5 to 2 min a sharp decrease was also observed. Such negative effect of prolonged blanching was also observed by Bellary and Rastogi (2014) on banana slices due to gelatinization of starch. The potato slices were also prone for starch gelatinization.
From Fig. 1a (i) it was also observed that the effect of calcium ion concentration was more direct i.e. as the calcium concentration increased in the solution, impregnation level or calcium content in the chips also increased linear manner. This linear behavior of fortificant concentration was also observed by Joshi et al. (2016).

Figure 1a (ii) reflected that with increase in restoration time, calcium impregnation increased initially in linear fashion followed by decrease in level of calcium impregnation i.e. quadratic function in later stage. Highest level of impregnation achieved at restoration time of $15 \mathrm{~min}$. It was due to the fact that Restoration time of 15 min was sufficient enough to incorporate the desired level of calcium to the potato chips. In favor of the findings Palou and Welti-Chanes (2003) reported that with the help of restoration time, when a porous tissue is immersed in a PAC concentrated solution under vacuum conditions, air is extracted from the pores and then, when atmospheric pressure is restored, the impregnation solution penetrates the intercellular spaces by capillary action and by the pressure gradient (i.e. the Hydrodynamic mechanism, HDM) that are imposed to the system, helping incorporation of PACs without exposing the food structure to the eventual stress.

As far as the whole model is concerned, the model has been significant $(\mathrm{p} \leq 0.05)$ having $\mathrm{F}$ value 8.43 and $\mathrm{R}$-square 0.907 . The value of adequate precision which measures signal to noise ratio was $10.8(\geq 4.0)$. This shows that the model can be used to navigate the design space.

\subsection{Fortification Confirmation}

The developed potato chips using optimized conditions (calcium chloride concentration, blanching time, vacuum level and rest period were at $1.20 \%, 1.33 \mathrm{~min}$, $40 \mathrm{~mm} \mathrm{Hg}, 12.01 \mathrm{~min}$ respectively) can be considered as rich source of calcium with 
acceptable sensory scores $(\geq 8.1$ on 9.0 -point Hedonic scale vs. 8.0 of control preparation) (Fig. 2).

\subsection{Physicochemical analysis}

\subsubsection{Compositional Analysis}

Proximate analysis of optimized fortified chips are shown in Table 3. As observed, there were no significant difference between the proximate composition of fortified potato chips and control potato chips except in ash and moisture content. Moisture content was found to be low in calcium fortified potato chips compared with control chips. This was due to the application of VI technique which has been reported to be associated with lowering the moisture content of the food products. In favor of the findings, Zhao and Xie (2004) reported that VI removes most of the water from the product thereby reducing energy consumption. Moreover, the dehydration of samples results in decrease in the cellular respiration rate and, consequently, an increase in the shelf-life of the processed fruit, both of which are more marked if calcium is added to the sample (Moraga et al., 2008).

Fortified samples were also reported to have high ash content in comparison with control potato chips. This was due to mineral fortification which led to higher ash content

\subsubsection{Oil Content}

Current experimental results showed that oil uptake for that for vacuum fried chips were low $(30 \%)$ compared to atmospheric frying $(42 \%)$. Oil reduction may be due to the lower vapour pressure of water during vacuum frying and the lower temperatures reaching during the process, as opposed to atmospheric frying, where important structural changes, which increase oil absorption. Thus, developed product can be a good alternative for nutritious foods.

\subsubsection{Mineral estimation}

Mineral estimation reflected that an optimized calcium fortified potato chips (800 $\mathrm{mg} / 100 \mathrm{~g}$ ) had 8.57 times and 5.17 times higher calcium content in comparison to its control (93.3 mg/100g) and commercial $(154.65 \mathrm{mg} / 100 \mathrm{~g})$ counterparts respectively.

\subsubsection{Color Analysis}

The $\mathrm{L}^{*}, \mathrm{a}^{*}$ and $\mathrm{b}^{*}$ of control potato chips were $\mathrm{L}^{*}: 64.60 \pm 1.831$; $\mathrm{a}^{*}:-2.09 \pm 0.273$; $b^{*}: 17.51 \pm 1.315$ respectively. Lightness (L value) is utmost important color parameter for fried foods and is usually used as a quality control determinant (Mariscal et al., 2008). Results indicated that lightness increased as the calcium fortificant concentration increased. In favor of the findings, Saftner et al. (2003) found treatments with calcium inhibited color changes and development of tissue translucency in honeydew chunks. Additionally, calcium can also help to keep longer the fresh-like appearance of minimally processed fruits and vegetables by controlling the development of browning. Control of the flesh browning has been observed in fruits in different studies, e.g. in peaches (Manganaris et al., 2007) and pineapple (Hewajulige et al., 2003).

Redness (a value) is an undesirable quality factor in fried foods (Krokida et al. 2001). Redness of potato chips was not found to be affected significantly with mineral fortification. Blanching at $72^{\circ} \mathrm{C}$, selection of low reducing sugar variety, elevated temperature storage $\left(10^{\circ} \mathrm{C}-12^{\circ} \mathrm{C}\right)$ and medium temperature frying (Nourian et al., 2003) were the prominent reasons for unchanged redness color parameter. In the similar way, yellowness (b value) varied the least $(\mathrm{p} \geq 0.05)$ showing no significant effect of iron fortification on potato chips.

Thus, total color of fortified potato chips at an optimized condition (3\%) can be described as light yellow (L*: 67.54; $\mathrm{a}^{*}$ : $\left.2.15 ; b^{*}: 18.01\right)$ which was quite similar to 
commercial preparation i.e. fried potato chips (L*: 68.60; a*: 1.09; b*: 17.51). Improved colour, was the result of combined application of VI and blanching, because both have been reported to retain or improve the natural colour of the food product (Pedreschiet al., 2004: Alzamora et al., 2000)

\subsection{Structural Changes through SEM}

There were no significant difference observed between fortified potato chips cell structure and control potato chips cell structure as shown in figure 3(a) and 3(b), displayed that at 100x magnification. Even under magnified view at 500x (Figure 3(c) and 3(d)), it was observed that though there was some deposition of calcium on fortified fries cell periphery but granule appearance remained the same. SEM images revealed that VI can be considered as a tool in the development of new value added fruit or Vegetable products without disrupting their cellular structure, while conveniently modifying their original composition (Tiwari and Thakur, 2016). Current experiments were in line with the results of Gras et al. (2003) that many calcium ions of VI products existed only in the ICAS, not inside of cells. In the present study also, the calcium salts were also kept in the ICAS without disrupting internal cells. Moreover, with increase in calcium concentration, firmness also get increased. Current experimental results are in agreement with those reported by Luna-Guzman and Barrett (2000) and Saftner et al. (2003) that calcium chloride treatment improves the firmness and the quality of freshly cut cantaloupes and honeydew, respectively. This was the reason for better mouth-feel of calcium fortified potato chips compared with control potato chips.

\subsection{Consumer Evaluation}

Table 4 summarizes the consumer sensory evaluation of the developed fortified potato product. The hedonic scales results showed that the only significant difference ( $\mathrm{P}$ $\leq 0.05$ ) which occurred was with $9 \%$ ISP for overall flavor. No significant difference in overall impression of chips fortified with calcium using VI technique was observed. Moreover, chips fortified with calcium enhanced the overall texture. Similar observations were found in freshly cut cantaloupes and honeydew as reported by Luna-Guzman and Barrett (2000) and Saftner et al. (2003).

Table 1. Independent variables and their coded and actual values used for optimization

\begin{tabular}{|l|c|c|c|c|c|}
\hline Independent variable & \multirow{2}{*}{ Units } & \multirow{2}{*}{ Symbol } & \multicolumn{3}{|c|}{ Code Level } \\
\cline { 4 - 6 } & & & -1 & 0 & 1 \\
\hline Calcium salt concentration & $\%$ & $\mathrm{X}_{1}$ & 1 & 3 & 5 \\
\hline Blanching time & Min & $\mathrm{X}_{2}$ & 0 & 1 & 2 \\
\hline Vacuum pressure & Min & $\mathrm{X}_{3}$ & 25 & 40 & 55 \\
\hline Restoration time & Min & $\mathrm{X}_{4}$ & 10 & 15 & 20 \\
\hline
\end{tabular}

Table 2.The Box-Behnken design and experiment data for mineral impregnation in potato chips

\begin{tabular}{|c|c|c|c|c|c|c|}
\hline Treatments & \multicolumn{4}{|c|}{ Independent Variable } & \multicolumn{2}{c|}{ Dependent Variable } \\
\cline { 2 - 7 } & $\begin{array}{c}\mathrm{X}_{1} \\
\text { Calcium } \\
(\%)\end{array}$ & $\begin{array}{c}\mathrm{X}_{2} \\
\text { Blanching } \\
\text { Time (min) }\end{array}$ & $\begin{array}{c}\mathrm{X}_{3} \\
\text { Vacuum } \\
\text { pressure } \\
(\mathrm{mm} \mathrm{Hg})\end{array}$ & $\begin{array}{c}\mathrm{X}_{4} \\
\text { Restoration } \\
\text { period } \\
(\mathrm{min})\end{array}$ & $\begin{array}{c}\text { Calcium } \\
(\mathrm{mg} / 100 \mathrm{~g})\end{array}$ & $\begin{array}{c}\text { Hardness } \\
\text { (Newton) }\end{array}$ \\
\hline 1 & 1 & 1 & 40 & 15 & 615.71 & 447.96 \\
\hline
\end{tabular}




\begin{tabular}{|c|c|c|c|c|c|c|}
\hline 2 & 5 & 1 & 40 & 15 & 2449.94 & 591.01 \\
\hline 3 & 1 & 2 & 40 & 15 & 1812.54 & 342.17 \\
\hline 4 & 5 & 2 & 40 & 15 & 2471.74 & 505.20 \\
\hline 5 & 3 & 0 & 25 & 10 & 1326.64 & 625.92 \\
\hline 6 & 3 & 0 & 55 & 10 & 1574.44 & 407.99 \\
\hline 7 & 3 & 0 & 25 & 20 & 1469.94 & 501.44 \\
\hline 8 & 3 & 0 & 55 & 20 & 1861.10 & 536.94 \\
\hline 9 & 3 & 0 & 40 & 15 & 1800.34 & 561.15 \\
\hline 10 & 1 & 0 & 40 & 10 & 232.24 & 360.39 \\
\hline 11 & 5 & 0 & 40 & 10 & 802.74 & 447.96 \\
\hline 12 & 1 & 0 & 40 & 20 & 266.64 & 415.75 \\
\hline 13 & 5 & 0 & 40 & 20 & 1848.94 & 443.96 \\
\hline 14 & 3 & 1 & 25 & 15 & 1395.54 & 545.52 \\
\hline 15 & 3 & 2 & 25 & 15 & 1220.64 & 312.00 \\
\hline 16 & 3 & 1 & 55 & 15 & 1427.14 & 543.64 \\
\hline 17 & 3 & 2 & 55 & 15 & 1879.0 & 412.22 \\
\hline 18 & 3 & 0 & 40 & 15 & 1598.74 & 348.99 \\
\hline 19 & 1 & 0 & 25 & 15 & 297.44 & 562.79 \\
\hline 20 & 5 & 0 & 25 & 15 & 1950.94 & 466.88 \\
\hline 21 & 1 & 0 & 55 & 15 & 215.24 & 452.54 \\
\hline 22 & 5 & 0 & 55 & 15 & 1147.74 & 476.40 \\
\hline 23 & 3 & 1 & 40 & 10 & 1504.84 & 321.01 \\
\hline 24 & 3 & 2 & 40 & 10 & 1483.0 & 425.74 \\
\hline 25 & 3 & 1 & 40 & 20 & 1820.74 & 407.05 \\
\hline 26 & 3 & 2 & 40 & 20 & 1443.2 & 533.29 \\
\hline 27 & 3 & 0 & 40 & 15 & 1696.84 & 448.66 \\
\hline
\end{tabular}

Table 3. Physicochemical analysis of an optimized fortified potato chips

\begin{tabular}{|c|c|c|c|c|}
\hline \multirow[t]{2}{*}{ Properties } & \multirow[t]{2}{*}{ Control } & \multicolumn{3}{|c|}{ Mineral (Calcium) Addition } \\
\hline & & $1 \%$ & $3 \%$ & $5 \%$ \\
\hline \multicolumn{5}{|c|}{ Proximate Composition } \\
\hline Protein $(g / 100 g)$ & $7.6 \pm 0.1^{\mathrm{a}}$ & $7.4 \pm 0.1^{b}$ & $7.5 \pm 0.1^{\mathrm{c}}$ & $7.5 \pm 0.0^{d}$ \\
\hline Fat $(g / 100 g)$ & $18.98 \pm 0.0^{\mathrm{a}}$ & $15.24 \pm 0.1 \mathrm{a}$ & $15.35 \pm 0.0 \mathrm{a}$ & $15.38 \pm 0.1 \mathrm{a}$ \\
\hline Ash $(g / 100 g)$ & $3.74 \pm 0.0^{\mathrm{a}}$ & $4.7 \pm 0.0^{\mathrm{a}}$ & $5.9 \pm 0.0^{\mathrm{a}}$ & $6.8 \pm 0.0^{\mathrm{b}}$ \\
\hline
\end{tabular}




\begin{tabular}{|c|c|c|c|c|}
\hline $\begin{array}{l}\text { Moisture } \\
(\mathrm{g} / 100 \mathrm{~g})\end{array}$ & $3.45 \pm 0.1^{\mathrm{a}}$ & $2.01 \pm 0.1^{b}$ & $2.07 \pm 0.0^{c}$ & $2.04 \pm 0.1^{\mathrm{d}}$ \\
\hline $\begin{array}{l}\text { Carbohydrates } \\
(\mathrm{g} / 100 \mathrm{~g})\end{array}$ & $54.5^{\mathrm{a}}$ & $54.6^{\mathrm{a}}$ & $54.6^{\mathrm{a}}$ & $54.6^{\mathrm{a}}$ \\
\hline $\begin{array}{l}\text { Energy } \\
\text { (cal/100g) }\end{array}$ & $452.78^{a}$ & $439.65^{a}$ & $439.62^{a}$ & $439.60^{a}$ \\
\hline \multicolumn{5}{|l|}{ Minerals } \\
\hline $\begin{array}{l}\text { Calcium } \\
(\mathrm{mg} / \mathbf{1 0 0 g})\end{array}$ & $98.3 \pm 0.03^{a}$ & $525 \pm 1.12^{b}$ & $816 \pm 1.67^{c}$ & $999 \pm 3.23^{d}$ \\
\hline \multicolumn{5}{|l|}{ Color } \\
\hline Value L* & $67.60 \pm 2.11$ & $68.05 \pm 1.21$ & $68.54 \pm 0.18$ & $68.89 \pm 0.08$ \\
\hline Value $a^{*}$ & $-2.07 \pm 0.01$ & $-1.06 \pm 0.11$ & $-1.09 \pm 1.01$ & $-1.07 \pm 1.41$ \\
\hline Value b* & $17.51 \pm 0.61$ & $16.98 \pm 0.19$ & $16.38 \pm 1.61$ & $16.46 \pm 0.34$ \\
\hline
\end{tabular}

Table 4. Effect of calcium fortification on sensory evaluation of the potato chips

\begin{tabular}{|c|c|c|c|c|c|c|}
\hline $\begin{array}{c}\text { Potato } \\
\text { Chips }\end{array}$ & $\begin{array}{c}\text { Overall } \\
\text { Taste }\end{array}$ & $\begin{array}{c}\text { Overall } \\
\text { Flavor }\end{array}$ & $\begin{array}{c}\text { Overall } \\
\text { Color }\end{array}$ & Hardness & Crispiness & $\begin{array}{c}\text { Overall } \\
\text { acceptability }\end{array}$ \\
\hline $\begin{array}{c}\text { Control } \\
\text { Chips }\end{array}$ & $7.96 \pm 1.09^{\mathrm{a}}$ & $8.07 \pm 1.11^{\mathrm{a}}$ & $7.95 \pm 1.31^{\mathrm{a}}$ & $8.20 \pm 1.17^{\mathrm{a}}$ & $8.11 \pm 1.04^{\mathrm{a}}$ & $8.05 \pm 1.01^{\mathrm{a}}$ \\
\hline $\begin{array}{c}\text { Fortified } \\
\text { Chips }\end{array}$ & $7.58 \pm 1.14^{\mathrm{a}}$ & $7.38 \pm 1.10^{\mathrm{b}}$ & $8.56 \pm 1.05^{\mathrm{b}}$ & $8.01 \pm 1.07^{\mathrm{a}}$ & $8.06 \pm 1.01^{\mathrm{a}}$ & $8.12 \pm 0.93^{\mathrm{b}}$ \\
\hline
\end{tabular}

${ }^{\mathrm{a}-\mathrm{l}}$ Values with the different letters within the same column are significantly different at $\mathrm{p}<0.1$. Mean 土SD $(n=56) .1-9$ scale: $1=$ dislike extremely. $9=$ like extremely.
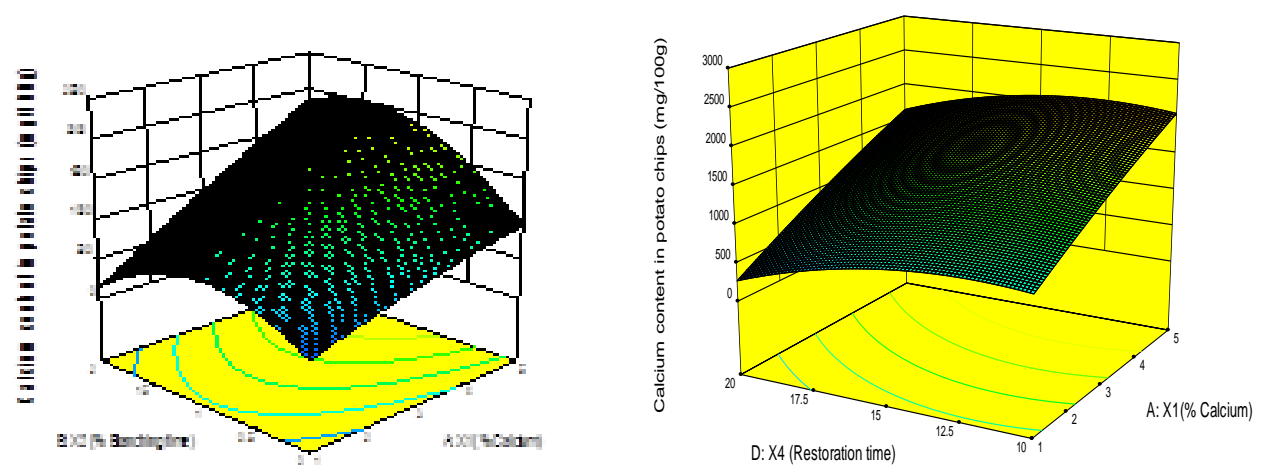

Figure 1a. Effect of i) blanching time and calcium concentration on calcium impregnation ii) restoration time and calcium concentration on calcium impregnation 


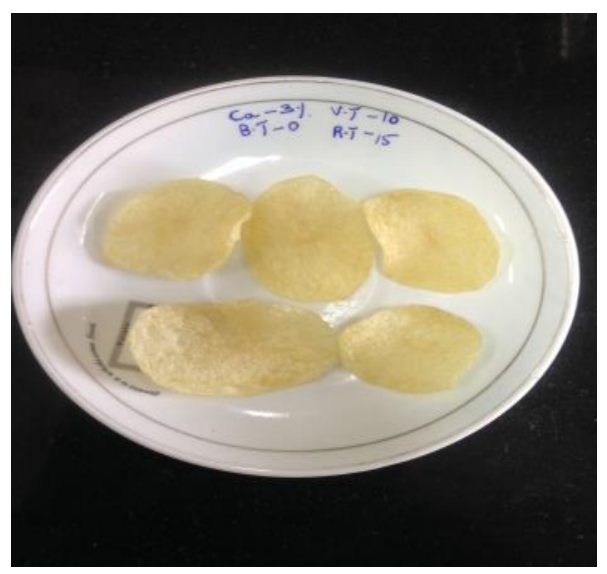

Figure 2. Calcium fortified chips

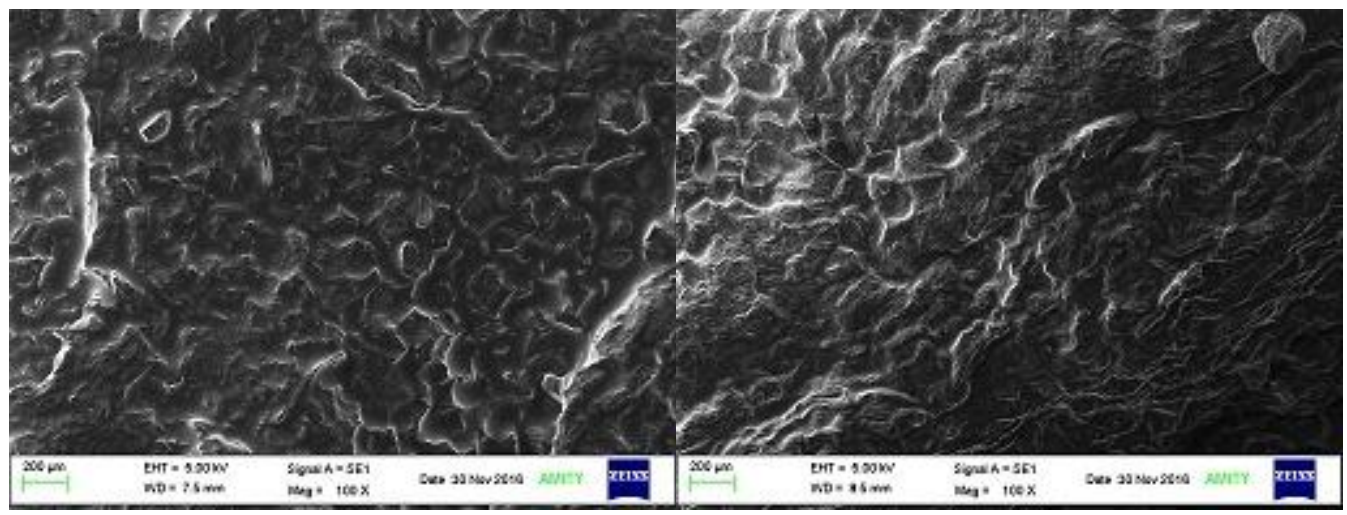

Figure 3a. Control Chips (100x) $\quad$ Figure 3b. Calcium fortified chips (100x)

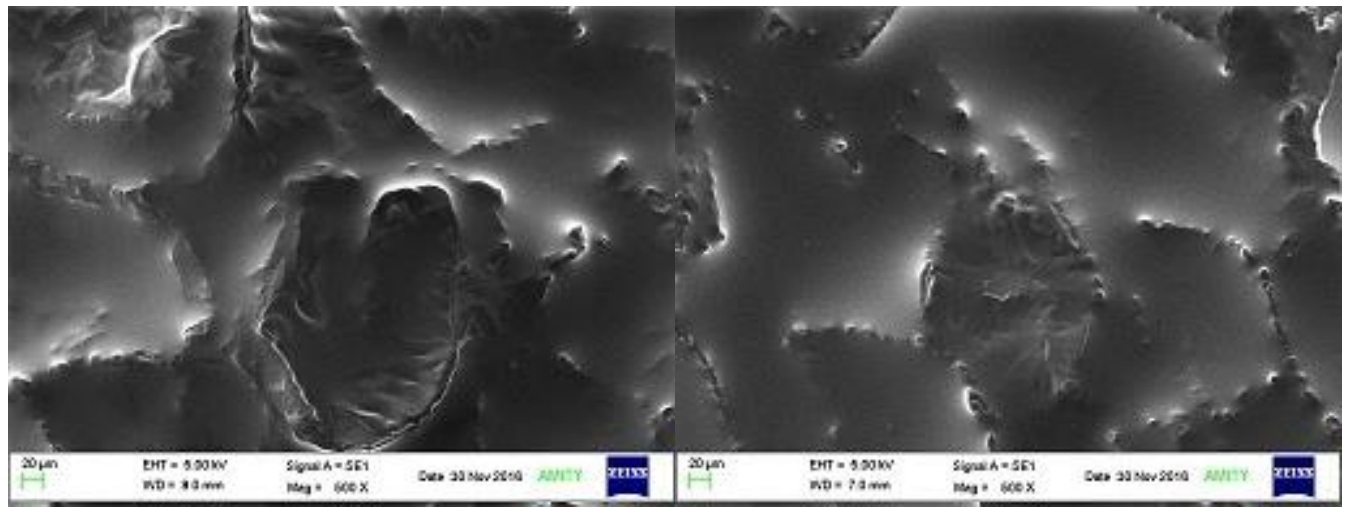

Figure 3c. Control chips (500x) Figure 3d. Calcium fortified chips (500x)

Figure 3. Structural effect of calcium impregnation in comparison with control

\section{Conclusions}

Impregnation treatment promoted significant changes in calcium concentrations, especially at $40 \mathrm{~mm} \mathrm{Hg}$ vacuum pressure for $15 \mathrm{~min}$ restoration time. The $\mathrm{Ca}^{2+}$ amount incorporated into the potato chips would satisfy about $25 \%$ of the adequate Intake for school aged children. 
SEM observation gave further insight in the cell structure and showed that although there was deposition of mineral on cell wall periphery, yet granule appearance remained the same. The descriptive structure attributes and consumer attributes demonstrated that fortification enhanced the chips texture by improving the firmness. In addition, low oil uptake percentage was found for vacuum fried iron fortified potato fries. Thus, calcium fortified potato chips were at par with commercial potato chips and can be proclaimed as healthy alternative to calcium intake.

\section{References}

Alzamora, S. M., Salvatori, D., Tapia, M. S., Lopez-Malo, A., Welti-Chanes, J., and Fito, P. (2005) Novel functional foods from vegetable matrices impregnated with biologically active compounds. Journal of Food Engineering, 67, 205214.

Bellary, A.N., Rastogi, N.K. (2014). Effect of Selected Pre-treatments on Impregnation of Curcuminoids and Their Influence on Physico-chemical Properties of Raw Banana Slices. Food Bioprocess Technology, 7, 2803-2812.

Bhatia, V. (2008) Dietary calcium intake-a critical reappraisal. Indian Journal of Medical Research ,127: 269 - 273.

Black, R. E., Allen, L. H., Bhutta, Z. A., Caulfield, L.E., and De Onis, M (2008) Maternal and child undernutrition: Global and regional exposures and health consequences. The Lancet,371, 243-260.

Erihemu, H.K., Koaze, H., Oda, Y., and Shimada, K. (2015) Zinc enrichment of whole potato tuber by vacuum impregnation. Journal of Food Science and Technology,52 (4),2352- 2358.

Food and Nutrition Board (2011). Institute of Medicine (USA), Dietary reference intakes for calcium and vitamin D. In; Ross AC, Taylor CL, Yaktine AL, del
Valle HB (eds), Washington DC, National Academy Press.

Gras, M. L., Vidal, D., Betoret, N., Chiralt, A., Fito, P (2003) Calcium fortification of vegetables by vacuum impregnation interactions with cellular matrix. Journal of Food Engineering,56, 279-284.

Harinarayan, C.V., Ramalakshmi, T., Prasad, U.V., Sudhakar, D., Srinivasarao, P.V.,Sarma, K.V., Kumar, E.G.(2007) High prevalence of low dietary calcium, high phytate consumption, and vitamin D deficiency in healthy south Indians. American Journal of Clinical Nutrition, 85,10621067.

Hewajulige, I. G. N., Wilson-Wijeratnam, R. S., Wijesundera, R. L. C.,Abeysekere, M. (2003). Fruit calcium concentration and chilling injury during low temperature $\mathrm{g}$ storage of pineapple. Journal of the Science of Food and Agriculture, 83, 1451-1454.

Hironika, H., Kikuchi, M., Koaze, H., Sato, T., Kojima, M., Yamamoto, K., Yasuda, K., Mori, M., Tsuda, S. (2011) Ascorbic acid enrichment of whole potato tuber by vacuum impregnation. Food Chemistry, 127, 1114-1118.

Joshi, A., Rudra, S. G., Sagar, V. R., Raigond, P., Dutt, S., Singh, B., Singh, B. P.(2016) Development of low fat potato chips through microwave processing. Journal of Food Science and Technology,53, 3296-3303.

Konar, N., Poyrazoglu, E.S., Artik, N. (2015) Influence of calcium fortification on physical and rheological properties of sucrose free prebiotic milk chocolates containing inulin and maltitol. Journal of Food Science and Technology, 52(4), 2033-2042.

Kumssa DB, Edward J, Joy M, Louise Ander E, Michael J, Watts Scott D, YoungSW, Martin RB (2014) Dietary calcium and zinc deficiency risks are decreasing but remain prevalent. 
Scientific Reports 5, Article number: 10974 (2015), doi:10.1038/srep10974

Larmond E. (1977). Laboratory methods for sensory evaluation of foods (p. 637). Ottawa, Canada: Department of Agriculture Ottawa.

Life extension update (2010) Insufficient calcium may link hypertension, osteoporosis

doihttp://www.lifeextension.com/Newsl etter/2010/6/Insufficient-Calcium-MayLink-Hypertension-Osteoporosis/Page01

Luna-Guzman, I., Barrett, D. M (2000). Comparison of calcium chloride and calcium lactate effectiveness in maintaining shelf stability and quality of fresh-cut cantaloupe. Postharvest Biology and Technology, 19, 61-72

Manganaris, G. A., Vasilakakis, M., Diamantidis, G., Mignani, I. (2007). The effect of postharvest calcium application on tissuecalcium concentration, quality attributes, incidence of fleshbrowning and cell wall physicochemical aspects of peach fruits.Food Chemistry, 4, 1385 1392.

Moraga, M. J., Moraga, G., Fito, P. J., Martínez-Navarrete, N. (2009). Effect of vacuum impregnation with calcium lactate on the osmotic Dehydration kinetics and quality of osmo-dehydrated grapefruit. Journal of Food Engineering, 90, 372-379.

Nourian, F., Ramaswamy, H. S., Kushalappa, A. C. (2003). "Kinetic changes in cooking quality of potatoes stored at different temperatures," Journal of Food Engineering. 60(3), 257-266, View at Publisher - View at Google Scholar • View at Scopus

Ranganna S. (2007). Handbook of analysis and quality control for fruit and vegetable products (2nd ed). New Delhi: Tata McGraw-Hill.

Raigond, P., Singh B, Gupta V K, and Singh B P. (2014). Potato flavour: Profiling of umami 5'-nucleotides from Indian potato cultivars. Indian Journal of Plant Physiology, 19(4), 338-344.

Raigond, P., Singh, B., Dhulia, A., Chopra, S., Dutt, S. (2015) Flavoring compounds in Indian potato snacks. Journal of Food Science and Technology,52, 8308-8314.

Saftner, R. A., Bai, J., Abbott, J. A., Lee, Y. S. (2003). Sanitary dips with calcium propionate, calcium chloride, or calcium amino acid chelates maintain quality and shelf stability of fresh-cut honeydew chunks. Postharvest Biology and Technology, 29, 257-269.

Sebastian R S, Goldman J D, Wilkinson Enns C, LaComb R P (2010). Fluid milk consumption in the United States: What we eat in America, NHANES 20052006. Food Surveys Research Group Dietary Data Brief No. 3. September 2010.

Tiwari, P.,Thakur, M. (2016). Vacuum impregnation: A novel non-thermal technique to improve food quality. International Journal of Current Research in Biosciences and Plant Biology,3, 117-126.

Torreggiani, D., Bertolo, G. (2001). Osmotic pre-treatments in fruit processing: chemical, physical and structural effects. Journal of Food Engineering,49(2-3), 247-253.

Zhao,Y, XieJ. (2004). Practical applications of vacuum impregnation in fruit and vegetable processing.Trends in Food Science \& Technology,15, 434-451. 